\title{
A single calibration of near-infrared spectroscopy to determine the quality of forage
}

\section{for multiple species}

\author{
Calibração única em espectroscopia de infravermelho próximo para determinar a qualidade de \\ múltiplas espécies de forragens \\ Calibración única en espectroscopia de infrarrojo cercano para determinar la calidad de múltiples \\ especies de forraje
}

Received: 08/02/2021 | Reviewed: 08/11/2021 | Accept: 08/16/2021 | Published: 08/18/2021

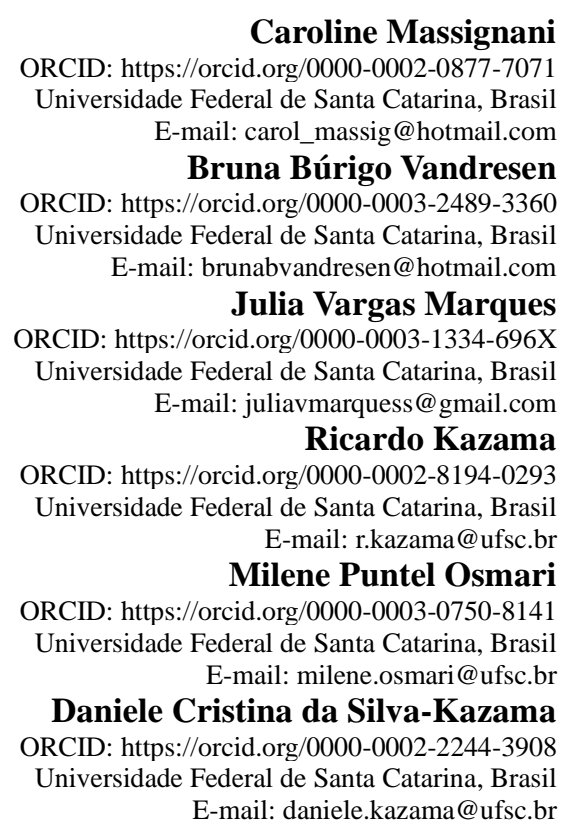

\begin{abstract}
Near-infrared spectroscopy (NIRS) is an efficient and chemical-free technique for quickly assessing forage quality. However, calibration curves are usually validated for the forage of a single species, while few studies have reported on the forage of multiple species. Therefore, this work aimed to develop a broad system of calibrating curves by NIRS to predict neutral detergent fiber (NDF), acid detergent fiber (ADF) and crude protein (CP) values from single and mixed forage. To accomplish this, single and mixed forage (32 forage species) were sampled over six years (2013 to 2019) from different regions of Santa Catarina state in southern Brazil. Forage samples were chemically analyzed for NDF, ADF and CP levels, followed by performing spectroscopy. Next, calibration curves were calculated as Second Derivative for NDF, First Derivative + Multiplicative Scattering Correction for ADF, and, Multiplicative Scattering Correction for CP. Approximately 200 sample forage, resulted in determination coefficient $\left(\mathrm{R}^{2}\right)$ values of $0.94,0.95$, and 0.98 and validation values of $0.94,0.95$, and 0.97 for NDF, ADF, and CP, respectively. Thus, calibration curves were properly developed for quality assessment of single or mixed forage for multiple species, resulting in a chemical-free and time-saving tool for routine laboratory use.
\end{abstract}

Keywords: Chemometrics; Crude protein; Fiber; Pasture; Ruminants.

\section{Resumo}

A espectroscopia no infravermelho próximo (NIRS) é uma técnica eficiente e livre de produtos químicos para avaliação rápida da qualidade da forragem. Porém, as curvas de calibração geralmente são validadas para uma única espécie de forragem e, há poucos estudos para forragens de múltiplas espécies. Assim, o objetivo deste trabalho foi desenvolver uma curva ampla de calibração pela técnica NIRS para predizer os valores de fibra em detergente neutro (FDN), fibra em detergente ácido (FDA) e proteína bruta (PB) de forragens simples e consorciadas. Assim, forragens simples e consorciadas (32 espécies de forrageiras) foram amostradas ao longo de seis anos (2013 a 2019) em diferentes regiões do estado de Santa Catarina, sul do Brasil. Amostras das forragens foram analisadas quimicamente 
quanto aos níveis de FDN, FDA e PB e, em seguida, os espectros foram lidos no espectrômetro. Para a calibração foram utilizados os tratamentos matemáticos Second derivative (FDN), First derivative + Multiplicative Scattering Correction (FDA), e Multiplicative scattering correction (PB). Com aproximadamente 200 amostras de forragens foi possível se alcançar valores de coeficiente de determinação $\left(\mathrm{R}^{2}\right)$ para a calibração de $0,94 \%, 0,95 \%$, e $0,98 \%$ e para a validação de 0,94\%, 0,95\%, e 0,97\% para os parâmetros FDN, FDA e PB, respectivamente. As curvas de calibração foram desenvolvidas adequadamente para avaliação da qualidade de forragens de múltiplas espécies (solteiras ou consorciadas) e podem ser usadas na rotina do laboratório sem produtos químicos e como uma ferramenta de rápida determinação.

Palavras-chave: Fibra; Pastagem, Proteína bruta; Quimiometria; Ruminantes.

\section{Resumen}

La espectroscopia de infrarrojo cercano (NIRS) es una técnica eficiente y libre de químicos para la evaluación rápida de la calidad del forraje. Sin embargo, las curvas de calibración generalmente se validan para una sola especie forrajera y existen pocos estudios para forraje de múltiples especies. Así, el objetivo de este trabajo fue desarrollar una amplia curva de calibración utilizando la técnica NIRS para predecir los valores de fibra detergente neutra (FDN), fibra detergente ácida (FDA) y proteína cruda (PC) de forrajes simples e mixtas. Así, se muestrearon forrajes simples e mixtas (32 especies forrajeras) durante seis años (2013 a 2019) en diferentes regiones del estado de Santa Catarina, sur de Brasil. Las muestras de forraje se analizaron químicamente para determinar los niveles de FDN, FDA y PC y luego se leyeron los espectros en el espectrómetro. Para la calibración se utilizaron los tratamientos matemáticos Second derivative (FDN), First derivative + Multiplicative Scattering Correction (FDA), e Multiplicative scattering correction (PC). Con aproximadamente 200 muestras de pastos fue posible alcanzar valores de coeficiente de determinación (R2) para la calibración de $0.94 \%, 0.95 \%$ y $0.98 \%$ y para la validación de $0.94 \%, 0.95 \%$ y $0.97 \%$ para los parámetros FDN, FDA y PC, respectivamente. Las curvas de calibración se han desarrollado adecuadamente para evaluar la calidad de forrajes de múltiples especies (individuales o mixtas) y se pueden utilizar de forma rutinaria en el laboratorio sin productos químicos y como una herramienta de determinación rápida.

Palabras clave: Fibra; Pasturas; Proteína cruda; Quimiometría; Rumiantes.

\section{Introduction}

Correct management of pastures, including forage planning, will ensure the self-sufficiency of feed supplies for livestock (Monrroy, Gutiérrez, Miranda, Hernández \& García, 2017). Feed-related costs are always a significant part of variable costs for all types of livestock production. Accordingly, recent research focuses on feeding and nutritional requirements as part of pasture management (Modroño, Soldado, Martínez-Fernández \& Roza-Delgado, 2017).

An alternative method to assess feed quality is near-infrared spectroscopy (NIRS), which is recognized as quick, cheap, accurate, nondestructive and free of chemicals (Lobos, Grou, Hube, Saldaña \& Alfaro, 2013; Frizon, Oliveira, Perussello, Peralta-Zamora, Camlofski \& Rossa, 2015; Ramirez, Posada, Handa, Hoch, Vohland, Messier \& Reu, 2015; Sánchez, Pérez-Marin, Torres, Garrido-Varo \& De la Haba, 2017), whereas the conventional chemical method is timeconsuming and labor-intensive (Decruyenaere, Lecomte, Demarquilly, Aufrere, Dardenne, Stilmant \& Buldgen, 2009; Monrroy et al., 2017). Thus, NIRS technology has been extensively used in agriculture and is considered a breakthrough in data collection, providing accurate and real-time information (Pasquini, 2003). Authenticated reference methods, spectral readings and mathematics make it possible to develop models of calibration and validation for pastures (Barros Neto, Scarminio \& Bruns, 2006). Even with a reduced number of insert measurements (105 samples), Parrini, Acciaioli, Crovetti and Bozzi (2018) obtained an excellent prediction for nutritive values of natural pastures using NIRS with determination coefficient of 0.99 for calibration values of NDF, ADF, and CP, as well as external validation of 0.99 for NDF and CP and 0.98 for ADF. However, calibration curves are usually validated for a single or a limited range of forage species (Azzouz, Puigdoménech, Aragay \& Tauler, 2003; Fontaneli, Scheffer-Basso, Durr, Appelt, Bortolini \& Haubert, 2004; Monrroy et al., 2017; Ullmann, Hermann, Hasler \& Taube, 2017; Yang, Nie, Pan, Zhang, Huang, Ma \& Zhang, 2017).

Nutritional values of pastures have a direct effect on livestock productivity. Accordingly, legumes mixed with grass forage may improve dry matter content and nutrient levels during the year (Barcellos, Ramos, Vilela \& Junior, 2008) and may ensure sustainability for milk production systems in southern Brazil (Fernandes, 2012). Consequently, using a wide variety of 
forage species, including grass and legumes, single or mixed, to develop calibration curves is a good strategy to reach the required variability among pasture management, seasonality and soil fertility to ensure accuracy in predicting the quality of samples. Some precedent-setting studies have already reported a single quality calibration curve for multiple species. For example, Lobos et al. (2013) reported eight forage species from pastures over two years in Chile. Molano, Cortés, Ávila, Martens \& Muñoz (2016) reported about 60 forage species from four different farms with different pasture management systems in Colombia. Parrini et al. (2018) reported 13 forage species over two years in Italy, and Norman, Hulm, Humphries, Hughes \& Vercoe (2020) reported more than 100 forage species cultivated in plots from different places in Australia.

The present study aimed to develop broad calibration curves by near-infrared spectroscopy (NIRS) to predict values of neutral detergent fiber (NDF), acid detergent fiber (ADF) and crude protein (CP) from single and mixed forage.

\section{Methodology}

\subsection{Sampling}

To conduced this research, characterized as experimental (Pereira, Shitsuka, Parreira \& Shitsuka, 2018), forage samples were obtained over six years (2013 to 2019), comprising all seasons of the year, from 150 dairy farms of different regions of Santa Catarina state, southern Brazil. Samples from single and/or mixed forage included 32 species of grasses and legumes with both temperate and tropical species. The grass species (26) were as follows: Andropogon lateralis Nees, Avena sativa, Axonopus affinis Chase, Axonopus compressus, Axonopus catharinensis, Axonopus obtusifolius (Raddi), Brachiaria brizantha cv. Piatã, Brachiaria brizantha, Brachiaria plantaginea, Cynodon dactylon cv. Jiggs, Cynodon dactylon cv. Tifton85, Cynodon Plectostachyus, Festuca arundinacea Schreb, Hemarthria altissima, Lolium multiflorum, Paspalum notatum, Pennisetum americanum, Pennisetum clandestinum, Pennisetum purpureum, Pennisetum purpureum Schum, Sorghum sudanense L., as well as the native grasses Ischaemum minus J. Presl (Poaceae), Eleocharis maculosa (Vahl) Roem. \& Schult., Rhynchospora holoschoenoides (Rich.) Herter, Rhynchospora tenuis (Cyperaceae) and Juncos tenuis Wild (Juncaceae). The legumes species (6) included Arachis pintoi, Desmodium adscendens (Sw.) DC., Desmodium incanum (Sw.) DC., Raphanus sativus L., Trifolium repens and Vica sativa.

Forages consisted of randomized samples collected from five points at each paddock using a $0.25 \mathrm{~m} 2$ square area. Samples were cut close to the ground, and green mass forages were stored in a paper bag. A composite sample of approximately $500 \mathrm{~g}$ per paddock was obtained, weighted and dried in a forced-air oven at $55^{\circ} \mathrm{C}$ for $72 \mathrm{~h}$, and then ground $(1$ $\mathrm{mm}$ ) in a Wiley mill.

\subsection{Reference analyzes}

Forage samples were also chemically analyzed, and these values were used as reference data for NIRS. Crude protein (CP) determination was analyzed by the Kjeldahl method (Association of Official Analytical Chemists [AOAC], 1995). Neutral detergent fiber (NDF) and acid detergent fiber (ADF) determinations were analyzed according to Van Soest, Robertson $\&$ Lewis (1991) based on the pre-dried values of samples.

\subsection{Calibration curves and validation}

Approximately $15 \mathrm{~g}$ of ground forage sample were transferred to a quartz background sample holder attached to a MPA FT-NIR device (BRUKER® OPTIK GmbH, Rudolf Plank Str. 27, D-76275 Ettlingen), and spectra were performed three times with 64 different scanned points with resolution of $16 \mathrm{~cm}^{-1}$ from 4.000 to $12.500 \mathrm{~cm}^{-1}$ of wavelength. Following the manufacturer's instructions, a background was done every 20 samples. 
Reference values of $\mathrm{CP}, \mathrm{NDF}$ and $\mathrm{ADF}$ were added to the spectra of forage samples. Construction of data pretreatment and chemometric models, i.e., development of calibration curves, was performed by Opus 7.5 software using the partial least squares (PLS) model (Bjorsvik \& Martens, 2001). The calibration model was adopted based on the smallest standard error of validation (root mean square error of cross validation (RMSECV) and the best value of determination coefficient (R2). Samples classified as outliers in graphs were detected and excluded from models. A sample set not included in the calibration step was used for external validation of curves.

\section{Results}

The original spectral set (Figure 1) used to develop NDF, ADF and CP calibration curves presented similarity, even considering that these spectra referred to a diversity of forage species $(n=32)$ among the grass and legumes collected. By applying mathematics and statistical modeling, spectral regions providing data about the analyzed nutrients were identified and selected for multivariate calibration to build regression models using PLS.

Figure 1. Original spectral set of diffuse reflectance on selected wavenumber of multiple species forage for calibration curve development: a. neutral detergent fiber (NDF); b. acid detergent fiber (ADF); c. crude protein (CP).
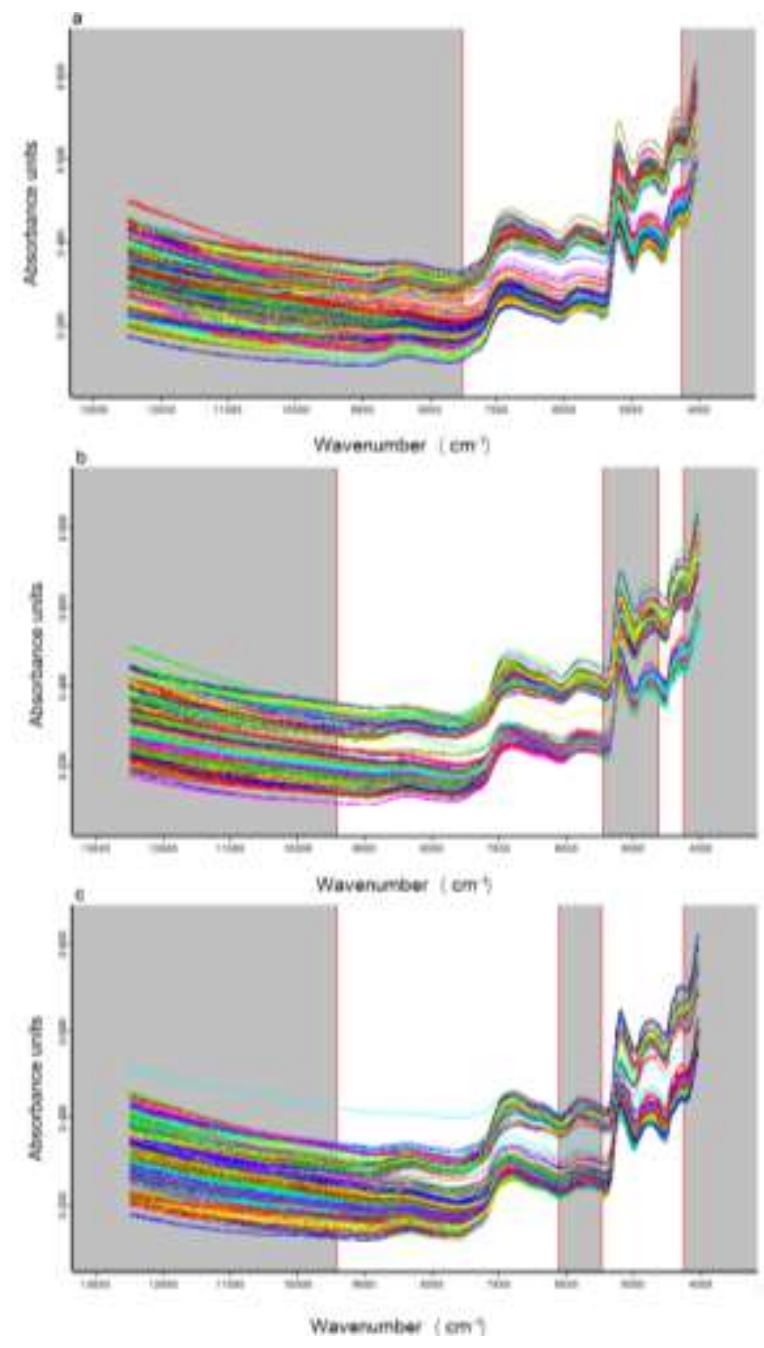

Source: Authors. 
Thus, combining interference-free pre-treatment and selection of more determinant regions for each component resulted in a converted spectral set (Figure 2). Pretreatments used for the forage spectral set presenting the best mathematical adjustments were Second Derivative (NDF, Figure 2.a), First derivative + Multiplicative Scattering Correction (ADF, Figure 2.b), and Multiplicative Scattering Correction (CP, Figure 2.c).

Figure 2. Forage spectral set of diffuse reflectance on wavenumber with mathematical adjustments for calibration curve development: a. neutral detergent fiber (NDF, second derivative); $\mathrm{b}$. acid detergent fiber (ADF, first derivative + multiplicative scattering correction); c. crude protein ( $\mathrm{CP}$, multiplicative scattering correction).
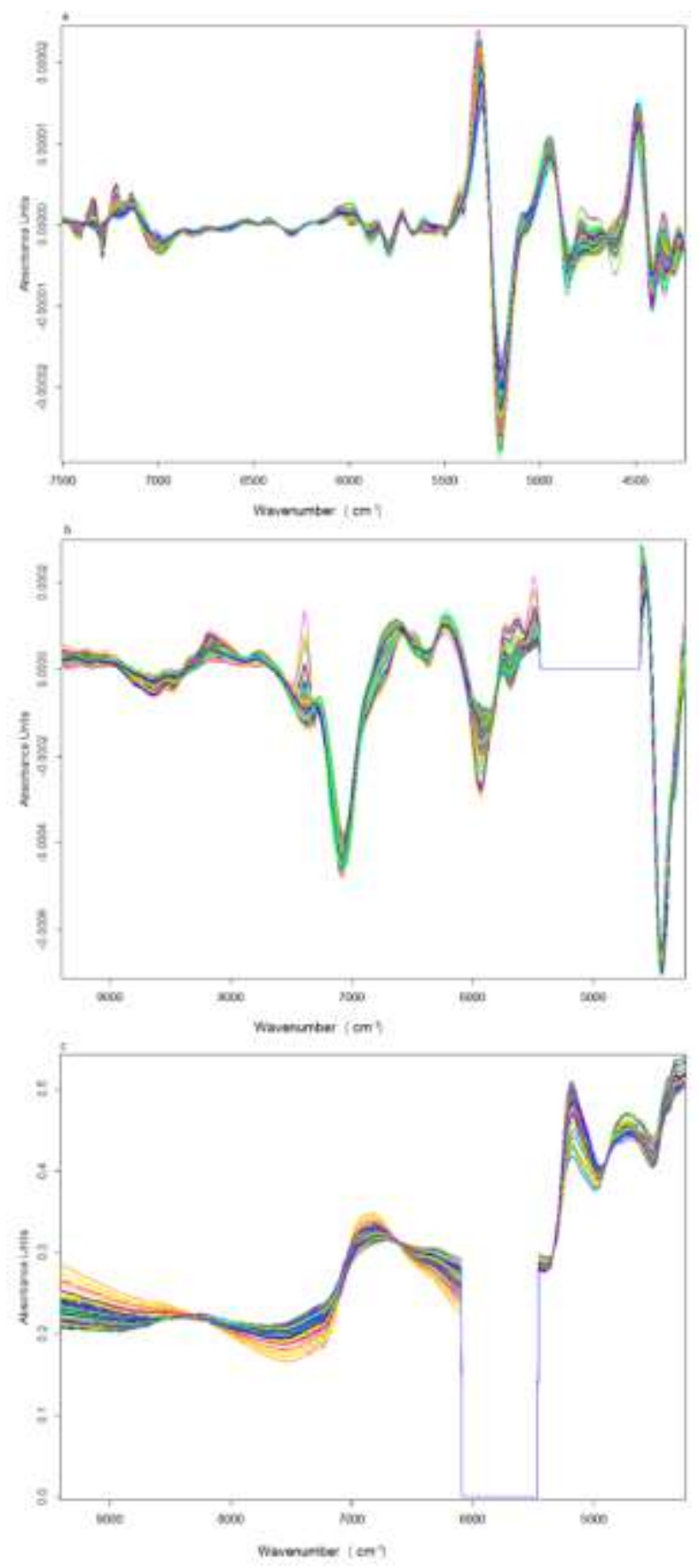

Source: Authors. 
Since the calibration set consisted of 32 different forage species, grasses and legumes, the NDF, ADF and CP components presented a large range (Table 1). Samples used for the NDF $(n=200)$ calibration curve presented reference values ranging from 30.19 to $69.95 \%$ of NDF, approximately. For the ADF calibration curve, samples $(\mathrm{n}=203)$ ranged from 17.04 to $42.74 \%$ of ADF, and for the CP calibration curve, samples $(n=196)$ ranged between 3.63 and $32.48 \%$ of CP.

Table 1. Reference values of NDF (neutral detergent fiber), ADF (acid detergent fiber) and CP (crude protein) for the calibration and external validation sets.

\begin{tabular}{|c|c|c|c|c|c|c|}
\hline & \multicolumn{3}{|c|}{ Calibration set } & \multicolumn{3}{|c|}{ External validation set } \\
\hline & Samples (n) & Min & Max & Samples (n) & Min & Max \\
\hline $\operatorname{NDF}(\%)$ & 200 & 30.19 & 69.95 & 20 & 30.17 & 68.08 \\
\hline $\operatorname{ADF}(\%)$ & 203 & 17.04 & 42.74 & 20 & 17.95 & 42.43 \\
\hline $\mathrm{CP}(\%)$ & 196 & 3.63 & 32.48 & 20 & 4.24 & 31.57 \\
\hline
\end{tabular}

Source: Authors.

The external validation sample set had components of amplitude similar to those of the calibration set. Values of NDF ranged from $30.17 \%$ to $68.08 \%$, ADF from $17.95 \%$ to $42.43 \%$, and $\mathrm{CP} 4.24 \%$ to $31.57 \%$.

After optimization, the calibration set (Table 2) presented a determination coefficient $\left(\mathrm{R}^{2}\right)$ of $0.95 \%$ and a RMSECV of 2.06 (mg. $\mathrm{g}^{-1}$ ) for NDF. ADF calibration presented a $\mathrm{R}^{2}$ of $0.96 \%$ and a RMSECV of 1.08 (mg.g ${ }^{-1}$ ), and CP calibration

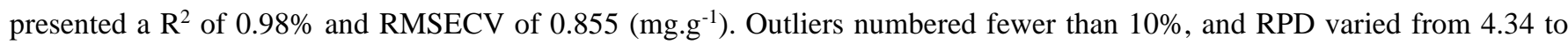
$7.23 \%$.

Table 2. Adjusted parameters and selected models errors of calibration set to predict values of neutral detergent fiber (NDF), acid detergent fiber (ADF) and crude protein (CP) from single and mixture forage.

\begin{tabular}{ccccccc}
\hline & Spectra $\left(\mathrm{n}^{*}\right)$ & Outliers $(\%)$ & $\begin{array}{c}\text { RMSECV } \\
\left(\mathrm{mg} \mathrm{g}^{-1}\right)^{\mathrm{a}}\end{array}$ & $\mathrm{R}^{2 \mathrm{~b}}$ & RPD (\%) & Equations \\
\hline $\mathrm{NDF}$ & 595 & 7.89 & 2.06 & 0.95 & 4.34 & $\mathrm{y}=0.948 \mathrm{x}+2.948$ \\
$\mathrm{ADF}$ & 605 & 8.92 & 1.08 & 0.96 & 4.75 & $\mathrm{y}=0.959 \mathrm{x}+1.344$ \\
$\mathrm{CP}$ & 588 & 9.35 & 0.86 & 0.98 & 7.23 & $\mathrm{y}=0.980 \mathrm{x}+0.199$ \\
\hline
\end{tabular}

"Forage samples performed three times; ${ }^{2} \mathrm{RMSECV}$ : root mean square error of cross validation; ${ }^{b} \mathrm{R}^{2}$ : cross validation coefficient of calibration step; 'RPD: residual predictive deviation. Source: Authors.

The external validation step (Table 3) was also performed with a sample set independent from the calibration set ( $\mathrm{n}=20$ ). For this sample set, the calibration step presented a coefficient of correlation $(r)$ of $0.94,0.96$ and 0.98 and RMSEP of 2.94, 2.07 and $1.78 \mathrm{mg} \mathrm{g}^{-1}$ for NDF, ADF and CP, respectively. RPD varied from 2.83 to $4.12 \%$. 
Table 3. Adjusted parameters and selected models errors for validation set of neutral detergent fiber (NDF), acid detergent fiber (ADF) and crude protein (CP) values from single and mixture forage.

\begin{tabular}{lccccc}
\hline & Samples $(\mathrm{n})$ & Spectra $\left(\mathrm{n}^{*}\right)$ & $\begin{array}{c}\text { RMSEP } \\
(\mathrm{mg} \mathrm{g}-1)^{\mathrm{a}}\end{array}$ & $r^{\mathrm{b}}$ & RPD (\%) \\
\hline $\mathrm{NDF}$ & 20 & 60 & 2.94 & 0.94 & 2.83 \\
$\mathrm{ADF}$ & 20 & 60 & 2.07 & 0.96 & 3.52 \\
$\mathrm{CP}$ & 20 & 60 & 1.78 & 0.98 & 4.12 \\
\hline
\end{tabular}

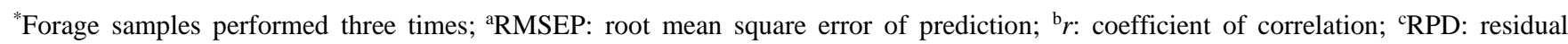
predictive deviation. Source: Authors.

\section{Discussion}

Instrument interference and baseline deviations were found to cause errors in the spectral set used for calibration (Figure 1). Therefore, it was necessary to apply pre-processing and spectral mitigation methods to rectify and standardize the impact of undesirable factors, but without altering spectroscopic information (Siesler, Ozaki, Kawata \& Heise, 2008; Azzouz et al., 2003). In this case, mathematics can be used to process data (Figure 2) to assist in the development of calibration curves and, moreover, improve their reliability (Neves, Soares, Morais, Costa, Porto \& Lima, 2012). Also, the difference between regions of selected spectra (Figure 1) for each component is possible because absorbance is measured by different molecular links at specific wavelengths, mainly $\mathrm{C}-\mathrm{H}, \mathrm{O}-\mathrm{H}$ and $\mathrm{N}-\mathrm{H}$, which are basic components of organic compounds from vegetable tissue (Bokobza, 2002).

A large sample range for each analyzed component is very desirable for developing a forage calibration curve (Table 1). Different species, such as grass and legumes, as well as other factors for the same species, such as geographic location, soil structure, environmental conditions, and grazing management, present variations in nutrient concentration (Kirkpinar \& Açikgöz, 2018). In addition, since external validation is a recommended tool for performance evaluation of prediction models (Lobos et al., 2013), the validation set should present an amplitude similar to that of the calibration set.

To adjust parameters (Table 2), during optimization, outliers from spectral limits of NIRS, or extreme values of calibration equations, were removed from the dataset, which did not surpass $10 \%$ of total evaluated spectra. This is a relevant step since outlier detection is an important task in multivariate calibration because quality of the calibration model is determined by the quality of calibration data (Li, Xu, Wang, Du, Cai \& Shao, 2016).

Fontaneli et al. (2004) developed calibration curves using NIRS to predict nutritive values of four types of Cynodon (Tifton 68, Tifton 85, Florakirk, Coastcross). They found high accuracy using 129 samples with $\mathrm{R}^{2}$ values of $0.98,0.97$ and 0.99 for CP, NDF and ADF, respectively. Lobos et al. (2013) evaluated nutritive quality from 295 samples of perennial pastures using NIRS, and they obtained $0.99\left(\mathrm{R}^{2}\right)$ calibration values for the CP component, $0.46\left(\mathrm{mg} . \mathrm{g}^{-1}\right)$ for RMSECV, and $10.5 \%$ for RPD. Moreover, for a large set of species, a study with 1991 samples of tropical grass and legumes was used to create calibration curves on NIRS. Models presented calibration coefficients $\left(\mathrm{R}^{2}\right)$ of 0.99 for the $\mathrm{CP}$ and NDF components and 0.95 for the ADF component. RPD values were, respectively, 7.3\%, 4.9\%, and 3.5\%, showing higher correlation between laboratory/chemical data than that obtained on NIRS (Molano et al., 2016). Similarly, our results achieved $\mathrm{R}^{2}$ above 0.9, indicating excellent prediction (Molano et al., 2016) for NDF (0.95), ADF (0.96) and CP (0.98) with around 200 samples. In addition, RPD values of NDF (4.34), ADF (4.75) and CP (7.23) were > 4.1, which was considered excellent by Williams (2014).

Ullmann et al. (2017) developed and validated calibration curves on NIRS for Lolium perenne L. harvested in 2012 and 2013 and reported $\mathrm{R}^{2}$ values of $0.99,0.91$ and 0.86 for $\mathrm{CP}, \mathrm{NDF}$ and ADF curves, respectively. Even with mixed forage in 
the present study, $\mathrm{R}^{2}$ values for NDF and ADF were higher than those obtained for single species pastures by Ullmann et al. (2017).

As mentioned before, according to Kirkpinar and Açikgöz (2018), pastures present highly variable concentrations of nutrients, depending on many factors. Therefore, obtaining information about the composition of forage nutrients is essential to decision-making in pasture management and, consequently, higher animal performance. In the laboratory, NIRS can be a chemical-free and time-saving tool for routine use, and in the field, it can be a tool to quickly determine the values similar to those reported in this work in order to improve feed resource management. In this sense, NIRS has been adopted as the official method by the Association of Official Analytical Chemists (AOAC) (1984) to predict CP concentration of forages. However, the use of this technique depends on an authenticated reference method, such as the Kjeldahl method (AOAC, 1995) because NIRS must correlate spectral characteristics with values obtained by an authenticated reference method (Pasquini, 2003).

Using the external validation step (Table 3) with a sample set independent from the calibration set is recommended to predict accurate values (Manley \& Baeten, 2018). Performing this step, we reached a coefficient of correlation ( $r$ ) above 0.94, and RPD values were completely satisfactory because, according to the guidelines of Williams (2014), an RPD of 2.83\% for NDF offers a fair screening potential, $3.52 \%$ for ADF is very good and $4.12 \%$ for CP is deemed excellent.

A study by Yang et al. (2017) developed and validated models with NIRS for the chemical composition of Lolium multiflorum, and an independent samples set was used to validate the NDF, ADF and CP variables, which resulted in $\mathrm{R}^{2}$ values of 0.91, 0.95 and 0.99, respectively, showing the accuracy of models in predicting these variables. Molano et al. (2016) used grass and legume species for external validation of NDF, ADF and CP variables and found " $r$ " values of $0.98,0.72$ and 0.94 , respectively, and RMSEP of 4.0, 4.2 and $1.8\left(\mathrm{mg}_{\mathrm{g}} \mathrm{g}^{-1}\right)$, respectively. We achieved exactly the same values for NDF and CP, but a better " $r$ " result for ADF, 0.96, and smaller RMSEP values of 2.94, 2.07 and 1.78 (mg.g ${ }^{-1}$ ) for NDF, ADF and CP, respectively.

Our results demonstrated that a unique calibration curve for multiple forage species is possible. To achieve this, according to Norman et al. (2020), it is necessary to include spatial, temporal and management diversity within the dataset, especially for feed testing laboratories where the diversity of growing sites and seasonality for forages, as well as forage management regimes, would be very high. Therefore, our dataset included samples from 2013 to 2019 from farms with different pasture management at different seasons and regions from Santa Catarina State in Brazil.

Finally, it is important that NIRS calibration curves be routinely modified over time to update results (Andueza, Picard, Martin-Rosset \& Aufrère, 2016).

\section{Conclusion}

Near-infrared spectroscopy can be used to develop models of calibration and validation for neutral detergent fiber, acid detergent fiber and crude protein of single or mixture forage, including grasses and legumes analyzed simultaneously. It allows the prediction of values with high correlation, and it is a chemical-free, nondestructive tool that is easy to use. It is suggested that new calibration curves be developed with a larger number of forage species, more than the 32 used in this experiment, to include as many species as possible.

\section{Acknowledgments}

The authors would like to thank to EPAGRI (Agricultural Research and Rural Extension Company of Santa Catarina) for collaborating in providing forage samples from farmers and CAPES (Coordination for the Improvement of Higher Education Personnel) for the scholarship awarded to Massignani, C. and CNPq (National Council for Scientific and Technological Development) for the scholarship to Marques, J. V. 


\section{References}

Andueza, D., Picard, F., Martin-Rosset, W., \& Aufrère, J. (2016). Near-infrared spectroscopy calibrations performed on oven-dried green forages for the prediction of chemical composition and nutritive value of preserved forage for ruminants. Applied Spectroscopy, 70, 1321-1327. https://journals.sagepub.com/doi/pdf/10.1177/0003702816654056 DOI: $10.1177 / 0003702816654056$.

Association of Official Analytical Chemists (1984). Official methods of analysis (14th ed.). Arlington: AOAC.

Association of Official Analytical Chemists (1995). Official methods of analysis (16th ed.) Arlington: AOAC.

Azzouz, T., Puigdoménech, A., Aragay, M., \& Tauler, R. (2003). Comparison between different data pre-treatment methods in the analysis of forage samples using near-infrared diffuse reflectance spectroscopy and partial least-squares multivariate calibration method. Analytica Chimica Acta, 484, 121-134. DOI: $10.1016 / \mathrm{S} 0003-2670(03) 00308-8$.

Barcellos, A. O., Ramos, A. K. B., Vilela, L., \& Junior, G. B. M. (2008). Sustentabilidade da produção animal baseada em pastagens consorciadas e no emprego de leguminosas exclusivas, na forma de banco de proteína, nos trópicos brasileiros. Revista Brasileira de Zootecnia, 37, 51-67. https://www.scielo.br/j/rbz/a/KwNbj7GpY83JLJFfxWRGNxr/?lang=pt DOI: 10.1590/S1516-35982008001300008

Barros Neto, B., Scarminio, I.S., \& Bruns, R. E. (2006). 25 anos de quimiometria no Brasil. Química Nova, 29, 1401-1406. https://www.scielo.br/j/qn/a/mQNsqf68QY9TmMw3KytvdvN/?lang=pt DOI: 10.1590/S0100-40422006000600042.

Bjorsvik, H. R., \& Martens, H. (2001). Data Analysis: Calibration of NIR Instruments by PLS Regression. In D. A. Burns, \& E. W. Ciurczak (Eds), Handbook of Near-infrared Analysis (pp. 185-208). New York: Marcel Dekker.

Bokobza, I. (2002). Origin of near-infrared absorption bands. In H. W. Siesler, Y. Ozaki, S. Kawata, \& H. M. Heise (Eds), Near-Infrared Spectroscopy: Principles, Instruments, Applications (pp. 11-42). Weinheim: Wiley-VCH.

Decruyenaere. V., Lecomte, P., Demarquilly, C., Aufrere, J., Dardenne, P., Stilmant, D., \& Buldgen, A. (2009). Evaluation of green forage intake and digestibility in ruminants using near infrared reflectance spectroscopy (NIRS): Developing a global calibration. Animal Feed Science Technology, 148, 138156. DOI: $10.1016 /$ j.anifeedsci.2008.03.007

Fernandes, C. O. M. (2012). Princípios da Produção de Leite a Pasto. In U. A. Córdova (Ed), Produção de leite à base de pasto em Santa Catarina (pp. 15-30). Florianópolis: Epagri.

Fontaneli, R. S., Scheffer-Basso, S. M., Dür, J. W., Appelt, J.V., Bortolini, F., \& Haubert, F. A. (2004). Predição da composição química de bermudas (Cynodon spp.) pela espectroscopia de reflectância no infravermelho proximal. Revista Brasileira de Zootecnia, 33, 838-842. https://www.scielo.br/j/rbz/a/WHhqdNqHKzWSKs6ks6nGyKQ/?format=pdf\&lang=pt. DOI: 10.1590/S1516-35982004000400003

Frizon, C. N. T., Oliveira, G. A., Perussello, C. A., Peralta-Zamora, P. G., Camlofski, A. M. O., Rossa, U. B., \& Hoffmann-Ribani, R. (2015). Determination of total phenolic compounds in yerba mate (Ilex paraguariensis) combining near infrared spectroscopy (NIR) and multivariate analysis. LWT-Food Science and Technology, 60, 795-801. DOI: 10.1016/j.1wt.2014.10.030

Kirkpinar, F., \& Açikgöz, Z. (2018). Feeding. In B. Yücel, \& T. Taşkin (Eds), Animal Husbandry and Nutrition (pp.97-114). London: IntechOpen.

Li, Z., Xu, G., Wang, J., Du, G., Cai, W., \& Shao, X. (2016). Outlier detection for multivariate calibration in near infrared spectroscopic analysis by model diagnostics. Chinese Journal of Analytical Chemistry, 44, 305-309. DOI: 10.1016/S1872-2040(16)60907-6

Lobos, I., Gou, P., Hube, S., Saldaña, R., \& Alfaro M. (2013). Evaluation of potential nirs to predict pastures nutritive value. Journal of Soil Science and Plant Nutrition, 13 (2), 463-468. https://scielo.conicyt.cl/pdf/jsspn/v13n2/aop3613.pdf. DOI: 10.4067/S071895162013005000036

Manley, M., \& Baeten, V. (2018). Spectroscopic technique: Near infrared (NIR) spectroscopy. In D. V. Sun (Ed.). Modern techniques for food authentication (pp. 51-102). Cambridge: Academic Press.

Modroño, S., Soldado, A., Martínez-Fernández, A., \& Roza-Delgado, B. (2017). Handheld NIRS sensors for routine compound feed quality control: Real time analysis and field monitoring. Talanta, 162, 597-603. DOI: 10.1016/j.talanta.2016.10.075

Molano, M. L., Cortés, M. L., Ávila, P., Martens, S. D., \& Muñoz, L. S. (2016). Ecuaciones de calibración en espectroscopía de reflectancia en el infrarrojo cercano (NIRS) para predicción de parâmetros nutritivos en forrajes tropicales. Tropical Grasslands - Forrajes Tropicales, 4, 139-145.

Monrroy, M., Gutiérrez, D., Miranda, M., Hernández, K., \& García, J. R. (2017). Determination of brachiaria spp. forage quality by near-infrared spectroscopy and partial least squares regression. Journal of the Chilean Chemical Society, 62 (2), 3472-3477. https://scielo.conicyt.cl/pdf/jcchems/v62n2/art10.pdf. DOI: $10.4067 / \mathrm{S} 071797072017000200010$

Neves, A. C. O., Soares, G. M., Morais, S. C., Costa, F. S. L., Porto, D. L., \& Lima, K. M. G. (2012). Dissolution testing of isoniazid, rifampicin, pyrazinamide and ethambutol tablets using near-infrared spectroscopy (NIRS) and multivariate calibration. Journal of Pharmaceutical and Biomedical Analysis, 57, 115-119. DOI: 10.1016/j.jpba.2011.08.029

Norman, H. C., Hulm, E., Humphries, A. W, Hughes, S. J., \& Vercoe, P. E. (2020). Broad near-infrared spectroscopy calibrations can predict the nutritional value of $>100$ forage species within the Australian feedbase. Animal Production Science, 60, 1111-1122. https://www.publish.csiro.au/an/pdf/AN19310. DOI: 10.1071/AN19310

Parrini, S., Acciaioli, A., Crovetti, A., \& Bozzi, R. (2018). Use of FT-NIRS for determination of chemical components and nutritional value of natural pasture. Italian Journal of Animal Science, 17, 87-91. https://www.tandfonline.com/doi/full/10.1080/1828051X.2017.1345659. DOI: 10.1080/1828051X.2017.1345659

Pasquini, C. (2003). Near infrared spectroscopy: fundamentals, practical aspects and analytical applications. Journal of the Brazilian Chemical Society, 14, 198-219. https://www.scielo.br/j/jbchs/a/R8Z76mVbzwxk6RCYCLGkSnz/?format=pdf\&lang=en. DOI: 10.1590/S0103-50532003000200006 
Research, Society and Development, v. 10, n. 10, e548101018990, 2021

(CC BY 4.0) | ISSN 2525-3409 | DOI: http://dx.doi.org/10.33448/rsd-v10i10.18990

Pereira, S. A., Shitsuka, D. M., Parreira, F. J. \& Shitsuka, R. (2018). Metodologia da pesquisa científica. UFSM.

Ramirez, J. A., Posada, J. M., Handa, I.T., Hoch, G., Vohland, M., Messier, C., \& Reu, B. (2015). Near-infrared spectroscopy (NIRS) predicts non-structural carbohydrate concentrations in different tissue types of a broad range of tree species. Methods in Ecology and Evolution, 6, 1018-1025. https://besjournals.onlinelibrary.wiley.com/doi/epdf/10.1111/2041-210X.12391. DOI: 10.1111/2041-210X.12391

Sánchez, M. T., Pérez-Marín, D., Torres, I., Gil, B., Garrido-Varo, A., \& De la Haba, M. J. (2017). Use of NIRS technology for on-vine measurement of nitrate content and other internal quality parameters in intact summer squash for baby food production. Postharvest Biology and Technology, 125, 122-128. DOI: $10.1016 / j$.postharvbio.2016.11.011

Siesler, H. W., Ozaki, Y., Kawata, S., \& Heise, H. M. (2008). Near-infrared spectroscopy: principles, instruments, application. Weinheim: Wiley-VCH.

Ullmann, I., Herrmann, A., Hasler, M., \& Taube, F. (2017). Influence of the critical phase of stem elongation on yield and forage quality of perennial ryegrass genotypes in the first reproductive growth. Field Crops Research, 205, 23-33. DOI: 10.1016/j.fcr.2017.02.003

Van Soest, P. J., Robertson, J. B., \& Lewis, B. A. (1991). Methods for dietary fiber, neutral detergent fiber, and nonstarch polysaccharides in relation to animal nutrition. Journal of Dairy Science, 74, 3583-3597. DOI: 10.3168/jds.S0022-0302(91)78551-2.

Williams, P. (2014). The RPD statistic: a tutorial note. NIR News, 25, 22-26. Retrieved from https://journals.sagepub.com/doi/pdf/10.1255/nirn.1419. DOI: 10.1255/nirn. 1419

Yang, Z., Nie, G., Pan, L., Zhang, Y., Huang, L., Ma, X., \& Zhang, X. (2017). Development and validation of near-infrared spectroscopy for the prediction of forage quality parameters in Lolium multiflorum. PeerJ, 5, 3867. Retrieved from https://peerj.com/articles/3867/. DOI: 10.7717/peerj.3867. 